\title{
TÜRKÇEDE GÖRECELİ ZAMAN: -DIydI/-mIştI
}

\section{Muhammet Taha Yangin ${ }^{1}$}

\begin{tabular}{|c|c|}
\hline Makale & Özet \\
\hline DOI: $10.35452 /$ caless.2020.27 & \multirow{10}{*}{$\begin{array}{l}\text { Alanyazında zaman olgusuna ilişkin çeşitli çalışmalar yer almasına } \\
\text { karşın söz konusu çalışmalarda ele alınan zaman olgusu mutlak } \\
\text { zamandır. Bunun yanı sıra, Türkçede -mIştI ve -DIydI yapılanmalarının } \\
\text { öncelik göreceli zaman ifade ettiğine ilişkin görüşler yer alsa da göreceli } \\
\text { zaman olgusuna ilişkin alanyazında kapsamlı bir çalışma yer } \\
\text { almamaktadır. Bu çalışmada ise işlevsel baş olarak belirteçlerin kip, } \\
\text { görünüş ve zaman ulamlarıyla arasındaki ilişkinin var olduğunu } \\
\text { sayıltılayarak; -DIK adlaştırma biçimi ile iyelik ve bulunma durum } \\
\text { belirticileriyle oluşan belirtecimsi işlevindeki biçimin bulunduğu } \\
\text { tümcelerde öncelik göreceli zamanın ifade ettiği belirtilen -mIştI ve - } \\
\text { DIydI yapılarını inceledik. İncelediğimiz veriler sonucunda, -mIştI ve - } \\
\text { DIydI yapılarının yalnızca öncelik göreceli zamanını değil, belirli } \\
\text { dilbilgisel ve anlamsal koşullarda sonralık da ifade ettiğini saptadık. } \\
\text { Bununla birlikte, bu koşulların neler olduğunu belirledik. }\end{array}$} \\
\hline Anahtar Kelimeler & \\
\hline Zaman & \\
\hline Göreceli Zaman & \\
\hline Öncelik & \\
\hline Sonralık & \\
\hline Belirtecimsi Yantümce & \\
\hline Gönderim Tarihi: 07.10.2020 & \\
\hline Kabul Tarihi: 09.11.2020 & \\
\hline Yayın Tarihi: 21.11.2020 & \\
\hline
\end{tabular}

\section{RELATIVE TENSE IN TURKISH: -DIydI/-mIştI}

Article Info

DOI: $10.35452 /$ caless.2020.27

Keywords

Tense

Relative Tense

Anterior

Posterior

Adverbial Clause

Received: 07.10.2020

Accepted: 09.11.2020

Published: 21.11.2020

Abstract

Although there are various studies on the tense phenomenon in the literature, the tense phenomenon addressed in these studies is absolute tense. In addition to this, there is no extensive research in the literature on the relative tense phenomenon although there are arguments stating that -mIştI and -DIydI forms express anterior tense in Turkish. In this study, we examined -mIştI and -DIydI forms, which are stated to express anterior tense in the sentences containing the form in the adverbial function, which is formed by the nominalizer -DIK, possessive and locative markers, by assuming that there is a relation between adverb(ial)s as functional heads and the categories of tense, aspect and modality. As a result of the data we analyzed, we found out that -mIştI and -DIydI forms express not only anterior tense but also posterior tense in certain grammatical and semantic conditions. We also studied the determining conditions.

APA'ya göre alıntılama: Yangın, M. T. (2020). Türkçede göreceli zaman: -DIydI/-mIştI. Uluslararası Dil, Eğitim ve Sosyal Bilimlerde Güncel Yaklaşımlar Dergisi (CALESS), 2(2), 509-527.

Cited as APA: Yangın, M. T. (2020). Relative tense in Turkish: -DIydI/-mIştI. International Journal of Current Approaches in Language, Education and Social Sciences (CALESS), 2(2), 509-527.

1 (D) Dokuz Eylül Üniversitesi, Sosyal Bilimler Enstitüsü, Türkiye, taha.yg@gmail.com 


\section{Giriş}

Zaman olgusunu Comrie (1985) temelde mutlak zaman (ing. absolute tense) ve göreceli zaman (ing. relative tense) olarak iki boyutta ele almaktadır. Araştırmacı, zaman olgusuna ilişkin bu ayrımı önermedeki olayın, konuşma anı ve önermedeki referans noktasıyla arasındaki ilişkiye dayanarak yapmaktadır. Türkçe alanyazındaki çalışmalarda ise zaman olgusu genel olarak Comrie'nin (1985) mutlak zaman olarak belirttiği zaman boyutunda incelenmektedir (Uzun, 1998; Sezer, 2001; Kornfilt, 1997; van Schaaik, 2001 vd.). Zaman olgusunun mutlak zaman boyutunu inceleyen Türkçe alanyazındaki çalışmaların bulunmasına rağmen Türkçede göreceli zamana ilişkin kapsamlı bir çalışma yer almamaktadır. Oysaki Türkçedeki -mIştI ve -DIydI yapılanmalarının öncelik ifade ettiğini belirten görüşler bulunmaktadır (Johanson, 2016; Sezer, 2001):
a. Ali ödevini yap-mış-tı.
b. Ali ödevini yap-tı-ydt.

Söz konusu görüşlere göre, (1a)' daki -mIş ve $-(y) D I$ biçimleriyle; (1b)' de $-D I$ ve $-(y) D I$ biçimleriyle oluşturulan $-m I s ̧ t \imath$ ve $-D \imath y D \imath$ yapılanmaları geçmiş zaman kodlayan iki biçimin bir araya gelmesiyle öncelik göreceli zamanı ifade etmektedir.

$\mathrm{Bu}$ çalışmada ise dilbilgisel zaman kavramından yola çıkarak, göreceli zaman ulamını ve Türkçede göreceli zamanı ifade eden dilsel anlatımları ele aldık ve bu dilsel anlatımlardan tüm göreceli zamanları ifade edebilen tek yapılanma olan [-DIK + IYYE + BUL] yapılanmasıyla, Türkçede -mIştI ve -DIydI yapılanmalarının öncelik göreceli zamanını ifade eden bir yapılanma olup olmadığını saptamayı amaçladık.

\section{Artalan}

\subsection{Zaman ve Göreceli Zaman Olgusu}

Dünya dillerinde zaman kavramı temelde mutlak zaman ve göreceli zaman olarak iki boyuta ayrılmaktadır. Mutlak zaman, konuşma anıyla ilişkili olan bir zamandır ve şimdiki zaman (ing. present tense), geçmiş zaman (ing. past tense) ve gelecek zaman (ing. future tense) olmak üzere üç temel başlıktan oluşmaktadır. Mutlak zamanın ifade ettiği zaman, konuşma anını temel almaktadır (Comrie, 1985). Mutlak zamanın ifade ettiği zamanın konuşma anıyla olan ilişkisi aşağıdaki gibidir: 
(2) Şimdiki Zaman $(\mathrm{O}=\mathrm{K})$

Olay ve konuşma anı eşzamanlıdır.

Geçmiş Zaman $(\mathrm{O}<\mathrm{K})$

Olay konuşma anından öncedir.

Gelecek Zaman $(\mathrm{O}>\mathrm{K})$

Olay konuşma anından sonradır.

Yukarıda olay $(\mathrm{O})$ ve konuşma anı $(\mathrm{K})$ arasındaki ilişki doğrultusunda belirtilen mutlak zamanlar görülmektedir. Anlatılan olayın, konuşma anı ile eşzamanlı olarak gerçekleşmesi şimdiki zaman; anlatılan olayın konuşma anından öncesinde olması durumu geçmiş zaman; anlatılan olayın, konuşma anından sonrasına gönderimde bulunması ise gelecek zaman olarak değerlendirilmektedir:

\section{Mutlak Zaman}

a. Şimdi Zaman

Ali şu anda kitap okuyor.

b. Geçmiş Zaman

Ali dün kitap okuyordu.

c. Gelecek Zaman

Ali yarın sinemaya gidecek.

Mutlak zamanı oluşturan üç zaman başlığıyla birlikte verilen (3) tümcelerdeki olay ve konuşma ilişkisine yönelik; (3a)'da konuşma anı ve olayın eşzamanlı gerçekleştiğini; $(3 b)^{\prime}$ de olay, konuşma anının öncesinde yer aldığını; (3c)'de ise ifade edilen olay konuşma anından sonrasında bulunduğunu söyleyebiliriz.

Mutlak zamanın üç başlık altında incelenmesinin yanı sıra, zaman kimi dillerde geçmiş (ing. past) ve geçmişdışı (ing. non-past) ya da gelecek (ing. future) ve gelecekdışı (ing. nonfuture) ikilikleriyle de kodlanabilir (Comrie, 1985). Bu ikiliklerin aksine, herhangi bir dilde zaman şimdiki ve şimdiki-dışılık gibi bir zaman ikiliği bulunmaz. Geçmiş ve geçmişdışı zaman ayrımına sahip dile İngilizceyi örnek gösterebiliriz. Gelecek ve gelecekdışı zaman ayrımına sahip dillerden birisi ise Huaca dilidir:

Ingilizce

$\begin{array}{lll}\text { a. I like-d horse-s. } \\ \text { ben beğen-GEÇ } & \text { at-ÇĞL }{ }^{2}\end{array}$

${ }^{2}$ Çalışmada yer verdiğimiz dilbilgisel gösterimlerde kullandığımız kısaltmalar şu şekildedir: 1K: birinci kişi, 1TKL: birinci tekil kişi, ADL: adlaştırıcı, BEL: belirtme durumu, BELCi: belirteçleştirici, BTŞ: bitmiş görünüşü, BUL: bulunma durumu, BÜT: bütünsellik görünüşü, ÇĞL: çoğullayıcı, EşZAM: eşzamanlılık, 
'Atları severdim.'

b. I like horse-s.

ben beğen.GEÇDIŞ at-ÇĞL

'Atları severim.'

Huaca (Papua Yeni Gine)

a. hu-Ku-ne yap- GEL.1K-ÇĞL

'Biz onu yapacağ 1 .'

b. hu-ne yap.1K-ÇĞL

'Biz onu yaptık.'

(Haiman, 1980, s. 158)

(4)'te verilen like (tr. beğen-) eylemi, (4a)'da geçmiş zamanla biçimlenmişken; (4b)'de geçmiş zaman belirticisiyle çekimlenmediği için, eylem biçimi geçmişdışı zamana gönderimde bulunmaktadır. (5)'te ise $h u$ (tr. yap-) eylemi, (5a)'da gelecek zamanla biçimlenmişken; (5b)'de eylem biçiminde gelecek zaman belirten bir biçim bulunmamasından dolayı gelecekdışı zamanı ifade etmektedir.

Konuşma anını temel alarak, olay ya da durumun belirttiği zamanın bilgisini aktaran geçmiş/geçmişdışı ve gelecek/gelecekdışı zaman ikiliklerinin yanı sıra, dilde olay ve önermedeki referans noktasını temel alarak ifade edilen bir diğer zaman boyutu ise göreceli zamandır (Comrie, 1985). Göreceli zamanın referans noktası (R) ve olay (O) arasındaki ilişkisi aşağıdaki gibidir:

a. Göreceli Şimdiki Zaman (Eşzamanlik) $(\mathrm{O}=\mathrm{R})$

Olay ve referans noktası eşzamanlıdır.

b. Göreceli Geçmiş Zaman (Öncelik) $(\mathrm{O}<\mathrm{R})$

Olay, referans noktasından öncedir.

c. Göreceli Gelecek Zaman (Sonralı) $(\mathrm{O}>\mathrm{R})$

Olay, referans noktasından sonradır.

(6)'da olay ve referans noktası arasındaki ilişki doğrultusunda belirtilen göreceli zamanlar bulunmaktadır. Olay ve referans noktası eşzamanlı gerçekleşerek göreceli şimdiki zamanı; olay, referans noktasından öncesine gönderimde bulunarak göreceli geçmiş zamanı; olay, referans noktasından sonrasına gönderimde bulunarak göreceli

GEÇ: geçmiş zaman, GEÇDIŞ: geçmişdışı zaman, GEL: gelecek, iYE: iyelik durumu, KONU: konulaştırıcı, ÖNC: öncelik, SNR: sonralık, YÖN: yönelme durumu. 
gelecek zamanı ifade etmektedir. Göreceli zamanların dildeki görünümlerini aşağıdaki örneklerde inceleyelim:

Japonca

a. Taroo-wa terebi-o mi-ta ato-de benkyoo-suru.

Taro-KONU televizyon-BEL izle-ÖNC sonra-BUL ders çalış-GEÇDIŞ

'Taro televizyon izledikten sonra ders çalışacak.'

(Bohnemeyer, 2014, s. 945)

\section{Kituba}

b. Ntángu ya María ata kwis, múna béto méne di-áka. zaman BÜT Maria SNR gel sonra biz BTŞ ye-ÖNC

'Maria geldiğinde, biz yemek yemiş olacağ1z [uzun bir süre önce].'

(Mufwene, 1990, s. 100)

\section{Çuvaşça}

c. Nina kil-e kil-sen әp'e Boris kil-ni

Nina ev-YÖN gel-EŞZAM.BELCI ben Boris gel-GEÇ:ADL

sineen pel-t-em.

hakkında bil-GEÇ-1TKL

'Boris'in vardığını, Nina eve geldiğinde öğrendim.'

(Hengeveld, 1998, s. 340)

(7a)'da öncelik belirten -ta biçimi ile biçimlenen mi- (tr. izle-) eylemi, benkyoo- (tr. ders çalış-) eyleminin ifade ettiği referans noktasından öncesinde gerçekleşmektedir. (7b)'de sonralık ifade eden ata dilsel anlatımiyla kwis (tr. gel-) eylemi, di- (tr. ye-) eyleminin belirttiği referans noktasının sonrasında gerçekleşmekte ve bu durumu, yine (7b) tümcesinde di- (tr. ye-) eylemi üzerinde bulunan -áka öncelik belirticisi tanitlamaktadır. (7c)'de ise kil- (tr. gel-) eylemi üzerinde biçimlenen hem belirteçleştirici hem de eşzamanlık -sen eki, kil- (tr. gel-) eyleminin, pel- (tr. bil-) eylemiyle aynı anda gerçekleştiğini belirtmektedir.

Bu noktaya kadar, olay ve konuşma anı arasındaki ilişkiye bağlı olarak belirtilen zamanın mutlak zaman ve olay ve referans noktası arasındaki ilişkiye doğrultusunda belirtilen göreceli zaman olmak üzere iki boyuttan oluştuğunu ve bu iki boyutu oluşturan alt ulamlar olduğunu gördük. Bu doğrultuda, zaman kavramına ilişkin yapılan yaygın sınıflandırma olarak aşağıdaki tabloyu gösterebiliriz: 
Çizelge 1. Dilde zaman ayrımı

\section{Zaman Göreceli Zaman}

- Geçmiş/Geçmişdışı Zaman

- Şimdiki (Eşzamanlı)

- Gelecek/Gelecekdışı Zaman

- Geçmiş (Öncelik)

- Gelecek (Sonralık)

Çizelge 1'de dillerde zaman ayrımının temelde iki boyuttan oluştuğu görülmektedir. Ayrıntılandırmak gerekirse, bir dilde zaman, geçmiş/geçmişdışı ya da gelecek/gelecekdışı ikiliklerinden biriyle aktarılırken; göreceli zamanla tümcede eşzamanlılık, öncelik ve sonralık durumları belirtilmektedir. Zamana ilişkin yaptığımız bu ayrımlar doğrultusunda, çalışmamızın bir sonraki başlığında Türkçedeki zaman ulamını ele alacağız.

\subsection{Türkçede Zaman Üzerine Çalışmalar}

Dillerde zaman ulamının geçmiş/geçmişdışı ya da gelecek/gelecekdışı ikilikleriyle belirtildiğinden bahsetmiştik. Uzun (1998), Türkçede zamanın geçmiş ve geçmişdışı ikiliğiyle belirtildiğini savunmakta ve bu doğrultuda, $-(y) D I$ biçiminin Türkçede geçmiş zamanı ifade ettiğini; geçmişdışı zaman için ise bir dilbilgisel biçim bulunmadığını belirtmektedir ${ }^{3}$. Eylemin -(y)DI ekiyle biçimlendiği tümcelerde olay ya da durum geçmiş zamanda; eylemin -(y)DI ekiyle biçimlenmediği tümcelerinde ise olay ya da durum geçmişdışı zamanda gerçekleşmektedir:
a. Ali dün kitap oku-yor- $d u$.
b. Ali kitap oku-yor.
c. ${ }^{*}$ Ali dün kitap oku-yor.

(8a)'da eylem üzerinde biçimlenen -(y)DI ekiyle tümcede verilen olay geçmişe gönderimde bulunurken; eylemin -(y)DI ekiyle biçimlenmediği (8b) tümcedeki olay ise geçmişdışı zamanda gerçekleşmektedir. (8c)'de ise $-(y) D I$ ekiyle geçmiş zamanın kodlanmadığı bir eylem biçiminin bulunduğu tümcede geçmişi ifade eden dün gibi bir belirteçle dilbilgisidışlık sergilediği görülmektedir.

Alanyazında, geçmiş ifade eden -(y)DI ekinin yanı sıra, $-D I$ ekinin de geçmişi ifade ettiği savunulmaktadır (Göksel ve Kerslake, 2005; Johanson, 2016; Kornfilt, 1997;

\footnotetext{
${ }^{3}$ Uzun (1998), geçmişdışı zamanı belirten bir sıfır ek ' $\emptyset$ ' bulunduğunu savunmaktadır. Ancak, bu çalışmada sıfır ek kullanımı yerine; geçmişdışı zamanın belirten bir ek olmadığı görüşünü savunmaktayız. Sıfır ek kavramına ilişkin detaylı bilgi ve inceleme için okuru Uzun (1998)'e yönlendiriyoruz.
} 
Underhill, 1976). Bu görüşün aksine, başka bir görüş ise $-D I$ ekinin, zaman belirtmediğini; bitmişlik görünüşünü ifade ettiğini savunmaktadır (Uzun, 1998). Alanyazında bu iki farklı görüşün bulunmasını aşağıdaki tümcelerde açıklamak mümkündür:

$$
\begin{aligned}
& \text { a. Ali dün gel-di. } \\
& \text { b. Ali dün gel-di-ydi. }
\end{aligned}
$$

Eyleminin -DI ekiyle biçimlendiği (9a) tümcesinde konuşma anından öncesine gönderimde bulunan dün belirtecinin kullanılabildiği görülmektedir. (9a) tümcesinde dün belirtecinin yer alabilmesiyle Türkçede -DI eki ile geçmiş zaman arasında bir ilişkinin olduğunu düşünülebilir. Ancak, $-D I$ ekinin geçmiş zaman belirttiği varsayılırsa, (9b)'de eylem biçiminde kodlanan ve geçmiş zaman belirticisi olan - $(y) D I$ ekinin kodlanamaması gerekir; başka bir deyişle, iki zaman belirticisi tek bir eylem biçiminde yer alamamaktadır. Bu durumda, (9b)'deki -DI ekinin geçmiş zaman dışında farklı bir dilbilgisel ulama gönderimde bulunması gerekmektedir. Bu noktada, Uzun'u (1998) izleyerek biz de -DI ekinin bitmişlik görünüşünü ifade ettiğini kabul ediyoruz. Bu doğrultuda, (9a) tümcesinde olduğu gibi dün belirtecinin kullanımına izin veren biçimin -DI bitmişlik görünüşü olduğunu; başka bir deyişle, zamana ilişkin bir belirtecin kullanımı için yalnızca zamansal gönderimi olan bir biçimin gerekli olmadığını söyleyebiliriz. Bu durumu aşağıdaki örneklerde de görmek mümkündür:

$$
\begin{aligned}
& \text { a. Ali dün gel-ecek-ti. } \\
& \text { b. Ali yarın gel-ecek-ti. }
\end{aligned}
$$

(10a) tümcesinde, konuşma anından öncesine gönderimde bulunan dün belirtecine izin veren - $(y) D I$ geçmiş zaman belirticisidir. (10b)' de ise konuşma anından sonrasına gönderimde bulunan yarın belirtecine izin veren biçimin - $(y) A c A k$ olasılık kipi olduğu; -(y)DI geçmiş zaman belirticisinin ise bu belirtecin kullanımını engellemediği görülmektedir. Bu durum, bir tümcede zamansal bir belirtecinin kullanımının yalnızca zaman belirticileriyle değil kip ve görünüş belirticileriyle de sağlandığını tanitlamakta ve tümcedeki zamansal bir belirtece, eylem biçimindeki bir ekin izin vermesinin söz konusu belirtecin kullanımı için yeterli olduğunu göstermektedir. Bu açıklama doğrultusunda, eylemlerinin $-D I$ ve $-(y) D I$ ekleriyle kodlandığı tümceleri inceleyelim:

$$
\begin{aligned}
& \text { a. Ali şimdi gel-di. } \\
& \text { b. }{ }^{*} \text { Ali şimdi gel-di-ydi. }
\end{aligned}
$$

Konuşma anına gönderimde bulunan şimdi belirtecinin bulunduğu tümcelerinden, (11a)'da şimdi belirtecinin kullanımına -DI ekinin izin verdiği 
düşünülürse, (11b) tümcesi de aynı şekilde şimdi belirtecinin kullanımına izin vermesi gerekmektedir. Ancak, (11b) tümcesi dilbilgisidışılık sergilemektedir. Bu durumda, (11a) tümcesinde aslında şu ana, konuşma anına gönderimde bulunan şimdi belirtecinin kullanımına izin veren biçimin -DI eki olmadığını, -(y)DI ekinin kodlanmamasıyla eylem biçiminin ifade ettiği geçmişdışı zamanın olduğunu söyleyebiliriz.

Dillerde bir diğer zaman boyutunun ise, göreceli zaman olduğunu ve göreceli zamanın, olay ve referans noktası arasındaki ilişki doğrultusunda ortaya çıktığından söz etmiştik. Yangın'da (2020) sunulan Türkçedeki göreceli zaman belirticileri aşağıdaki gibidir4:

Çizelge 2. Göreceli Zaman Belirten Biçimler

$$
\begin{aligned}
\text { Eşzamanlık } & -(I) \text { yorken / -(I)rken / -(y)ArAk / [-DIK + IYYE + sirada/zaman/esnada }] / \\
& {[-\mathrm{DIK}+\dot{\mathrm{IYE}}+\mathrm{BUL}] }
\end{aligned}
$$

Sonralık - -mAdAn önce / [-DIK + İYE + BUL]

$$
\begin{aligned}
& \text { Öncelik } \quad-(y) I n c A \text { / -mIşken / -(y)Ip / -(y)AlI / -(A/I)r...-mAz / -mAdAn / [-DIk + } \\
& \text { AYR + sonra] / [-DIK + IYYE + AYR + bu yana/itibaren] / [-DIK + İYE + } \\
& \text { BUL] / [-DIK + IYYE + anda/gibi] / [-DI + KIŞ்̧ ki] / [-DI + KIŞ்̧̇ mI] / [- } \\
& \mathrm{DI}+\mathrm{KISSI} \mathrm{dA}]
\end{aligned}
$$

Çizelge 2'de ifade ettikleri göreceli zamanlar ile sunulan dilsel anlatımların dildeki somut görünümlerini aşağıdaki örnek dökümünde inceleyelim:

\section{Eşzamanlık}

a. [Ali yürüyorken/yürürken] seni görmüş. - -(I)yorken / -(I)rken /

b. [Ali müzik dinleyerek] yürüdü. $\quad-(y) A r A k$

c. [Ali uyuduğu esnada] deprem olmuş. $\quad$ [-DIK + İYE + sırada/esnada]

d. [Onu gördüğümde] müzik dinliyordu. [-DIK + IYYE + BUL]

\section{Sonralik}

a. [Ali uyumadan önce] ödevlerini bitirdi. $\quad-m A d A n$ önce

b. [Ali geldiğinde] yemek pişmişti. [-DIK + İYE + BUL]

\section{Öncelik}

\footnotetext{
2 Yangın' da (2020) tüm belirteç yantümcelerin bir şekilde zamansal gönderiminin bulunduğu belirtilse de bu çalışmada yalnızca göreceli zamanı belirgin bir şekilde ifade eden Çizelge 2' deki dilsel anlatımları temel aldık. Belirteç yantümcelerine ilişkin daha kapsamlı bilgi için okuyucuyu Aydemir (2019) ve Yangın (2020)'ye yönlendiriyoruz.
} 

a. [Eve gelince] yemek pişirdi.
$-(y) \operatorname{Inc} A$
b. [Havalar ısınmışken] dışarı çıktık.
-mIşken
c. [Ödevimi yapıp] film izleyeceğim.
$-(y) I p$
d. [Seni göreli] kötü hissediyorum.
$-(y) A l I$
e. [Seni görür görmez] ağlayacak.
$-(A / I) r \ldots-m A z$
f. [Ders çalışmadan] okulu bitirdi.
$-m A d A n$
g. [Uyandıktan sonra] yemek yiyeceğim.
[-DIk + AYR + sonra]
h. [Geldiğinden beri] görüşmedik.
$[-\mathrm{DIK}+\dot{\mathrm{I} Y E}+\mathrm{AYR}+$
beri/bu yana/itibaren]
i. [Gördüğüm anda] hatırladım.
[-DIK + İYE + anda/gibi]
j. [O kadar çalıştı ki] elleri yara oldu.
[-DI + Kişì ki]
k. [Okul bitti mi] memlekete döneceğim.
[-DI + KİŞİ mI]
1. [Ödevimi yaptım da/yapıp da] geldim.
[-DI + Kişi்/-(y)Ip dA]
m. [Ali gözünü açtı̆̆ında] ilk beni gördü.
$[-\mathrm{DIK}+\dot{\mathrm{I} Y E}+\mathrm{BUL}]$

Türkçedeki göreceli zamanı ifade etmek için kullanılan dilsel anlatımları sunduğumuz Çizelge 2'deki her bir yapıyı yukarıdaki örnek dökümünde sırasıyla sunduk. (12)'de ayraçlı şekilde verilen yantümceler, ana tümcenin ifade ettiği zaman ile aynı zamanda gerçekleşir. (13)'te sunulan ayraçlı yantümceler, ana tümcenin gönderimde bulunduğun zamanın sonrasındaki bir zamana gönderimde bulunmaktadırlar. (14)'te verilen yantümceler ise ana tümcenin gönderimde bulunduğu zamanın öncesindeki bir zamana konumlanır.

Türkçede göreceli zamanı ifade etmek için kullanılan yapılanmaları Çizelge 2'de sunduk ve tümcedeki kullanımlarını (12-14) örneklerinde gördük. Bu örneklerde, göreceli zaman ifade eden yapılanmalardan [-DIK + IYYE + BUL] yapısının tüm göreceli zamanları ifade edebildiği görülmektedir:
a. [Onu gör-düğgüm-de] müzik dinliyordu.
(Eşzamanlık)
b. [Ali gel-diğ-in-de] yemek pişmişti.
(Sonralık)
c. [Ali gözünü aç-tı̆̆-ın-da] ilk beni gördü.
(Öncelik)

(15)'te sırasıyla eşzamanlık, sonralık ve öncelik durumlarını ifade eden ayraçlı yantümcelerin tümü [-DIK + İYE + BUL] yapısı ile biçimlenmektedir. Bu yapıyla oluşturulan ve sunulan ayraçlı yantümceler, (15a)'da dinle- eylemiyle aynı anda gerçekleşmekte; (15b)'de piş- eyleminden sonra gerçekleşmekte; (15c)'de ise göreyleminden önce gerçekleşmektedir.

Yangın'da (2020) [-DIK + IYYE + BUL] yapılanmasının eşzamanlık, sonralık ve öncelik olarak tüm göreceli zamanları ifade ettiği belirtilmekte; ancak, bu yapılanmanın hangi 
durumlarda hangi göreceli zamanları ifade ettiğini belirten kapsamlı bir bilgi ya da ayrıcı özellikler sunulmamaktadır. Bir sonraki başlıkta, Yangın'da (2020) [-DIK + İYE + BUL] yapılanmasına ilişkin yapılan açıklamaları ele alarak, bu yapının hangi göreceli zamanı hangi durumlarda ifade ettiğini belirlemeye çalışacağız.

\section{3. [-DIK + IYYE + BUL] ve Göreceli Zaman}

[-DIK + IYE + BUL] yapılanması, (15)'te ifade ettiği göreceli zamanlardan eşzamanlık durumunu, ana eylem biçiminin -(I)yor sürerlik biçimiyle yapılandığı durumlarda aktarabilmektedir:

(16) [Telefon çaldığında] bulaşık yıkıyordum.

(16) tümcesinde -(I)yor sürerlik biçimiyle çekimlenen yıka- ana eylemi, [-DIK + İYE + BUL] yapılanmasıyla oluşturulan yantümcenin çal- eylemi ile aynı anda, eşzamanlı olarak gerçekleştiği bilgisini vermektedir. Ana eylemin -(I)yor sürerlik biçimiyle çekimlendiği durumlarda, [-DIK + İYE + BUL] yapılanmasıyla oluşturulan yantümcenin eşzamanlık durumu belirtir. Bu doğrultuda, bu durumun eşzamanlılık göreceli zamanını belirten [-DIK + IYE + BUL] yapılanmasının, aynı yapılanmanın ifade ettiği diğer göreceli zamanlardan ayıran temel özellik olduğu söyleyebiliriz.

[-DIK + IYE + BUL] yapılanmasının eşzamanlık göreceli zamanı kodlamasının yanı sıra, sonralık göreceli zamanını da ifade ettiğini görmüştük. [-DIK + IYYE + BUL] yapılanması sonralık göreceli zamanını, ana eylemin -mIş bitmişlik ve $-(y) D I$ geçmiş zaman belirticileriyle (-mIştI) birlikte yapılandığı durumlarda ifade etmektedir:

[Eve geldiğimde] yemek pişmişti.

(17)'de yantümcenin gel- eylemi, -mIş bitmişlik ve -(y)DI geçmiş zaman belirticileriyle çekimlenen piş- ana eylemine göre sonralık belirtmektedir. Ancak, ana eylemin $-m I s ̧$ bitmişlik ve $-(y) D I$ geçmiş zaman belirticileriyle çekimlendiği her durumda, [-DIK + İYE + BUL] yapılanması sonralık göreceli zamanını belirtmez:

(18) [Eve geldiğimde] yemek yemiştim.

(Öncelik/Sonralık)

(18)'de yantümcenin gel- eylemi, -mIş bitmişlik ve -(y)DI geçmiş zaman belirticileriyle biçimlenen ana eylemine göre hem öncelik hem de sonralık durumlarını belirtmektedir. Öncül bir bağlamın sunulmasıyla, (18) tümcesinde [-DIK + İYE + BUL] yapılanmasının ifade ettiği öncelik ve sonralık göreceli zamanlarını daha belirgin hale getirebiliriz:

(19) Öncül Bağlam: Mutfakta neden kirli tabak var?

Y1: [Eve geldiğimde] yemek yemiştim.

(Öncelik)

Y2: Bilmiyorum, [eve geldiğimde] yemek yemiştim.

(Sonralık) 
(19)'da öncül bağlama verilen birinci yanıt (Y1) öncelik belirtirken; ikinci yanıt (Y2) sonralık belirtmektedir. Bu durum, ana eylemin - $m$ Iş bitmişlik ve - $(y) D I$ geçmiş zaman belirticileriyle biçimlendiği her durumda, [-DIK + IYYE + BUL] yapılanmasının yalnızca sonralık belirtmediğini, öncelik de belirtebildiğini göstermektedir. Bunun yanı sıra, [DIK + IYYE + BUL] yapılanmasının ifade ettiği öncelik/sonralık durumlarına bağlı olarak tümcedeki odak ${ }^{5}$ (ing. focus) farklılık göstermektedir:
a. [Eve geldiğimde] YEMEK yemiştim.
(Öncelik)
b. [Eve geldiğimde] yemek YEMişTiM.
(Sonralık)

(20a) tümcesinde odağın eylem öncesi, olağan konumunda; (20b) tümcesinde odak eylem üzerindedir. Bununla birlikte, [-DIK + IYYE + BUL] yapısının [+odak] özellikli bir biçimde tümcede yer alması [-DIK + IYYE + BUL] yapısının öncelik ifade ettiğini göstermektedir:

Yemek [EVE GELDİĞIMME] yemiştim.

(Öncelik)

(21)'de eylem önü, olağan odak konumunda bulunarak [-DIK + İYE + BUL] yapısının öncelik ifade ettiği görülmektedir. Bununla birlikte, ana eylemin -mIş bitmişlik ve (y)DI geçmiş zaman biçimlendiği durumlarda, [-DIK + İYE + BUL] yapılanmasının öncelik/sonralık göreceli zamanlarından hangisini ifade ettiğini çoktan belirteciyle belirleyebiliriz. Bağımsız bir dilbilgisel etmen olarak çoktan belirtecini kullanmamızın nedeni, bu belirtecin bir öncelik belirteci (ing. anterior adverb) olmasıdır. Öncelik belirteçleri eklendikleri eylemin öncelik/sonralık açısından önce gerçekleştiğini göstermektedir (Cinque, 1999; Yangın, 2020):

a. Ali dışarı çıkmadan önce çoktan işlerini bitirmişti.

b. *Ali dışarı çıktıktan sonra çoktan işlerini bitirmişti.

(22a) tümcesinde sonralık ifade eden Ali dışarı çıkmadan önce belirteç yantümcesinin, çoktan belirtecinin kullanımına izin verdiğini; (22b) tümcesinde ise öncelik ifade eden Ali dışarı çıktıktan sonra belirteç yantümcesinin, çoktan belirtecinin kullanımına izin vermediğini görmekteyiz. Bu durum, çoktan belirtecinin yalnızca önceliğin ifade edildiği tümcelerde yer aldığını göstermektedir. Bu doğrultuda, çoktan belirtecinin kullanımıyla önceliğin belirtildiği tümcelerde hem öncelik hem de sonralık ifade edebilen [-DIK + IYYE + BUL] yapılanmasıyla oluşturulan belirteç yantümcelerin sonralık ifade etmesi beklenir. Ancak söz konusu öncelik/sonralık durumunu belirleyen çeşitli etmenler bulunmaktadır:

\footnotetext{
5 Türkçede odak ve odaklamaya ilişkin daha geniş bilgi için okuyucuyu İşsever'e (2000)
} yönlendiriyoruz. 

a. \#[Eve geldiğimde] çoktan uyumuştum.
b. [Eve geldiğimde] çoktan yemek yemiştim.

(23a)'da yantümcenin gel- eyleminin, çoktan belirtecinin nitelendirdiği uyu-6 eyleminden önce gerçekleşmesi anlamsal açıdan bozuk iken; (23b)'de yantümcenin gel- eylemi, çoktan belirteciyle nitelendirilen ye- eylemine göre sonralık ifade etmektedir. Bu durum, yantümce ve ana tümcenin eylemleri arasındaki anlamsal ilişkinin, öncelik/sonralık durumlarını belirleyebildiğini göstermektedir. Anlamsal açıdan, -mIş ve -DI ekleriyle çekimlenen ana eylemin bahsettiği olay ya da durumun gerçekleşmesinden sonra gerçekleşebilecek olay ya da durumları belirten yantümcenin eylemi, hem öncelik hem de sonralık göreceli zamanlarını ifade edebilmektedir. Bu durum, ana eylem ve yantümce eylemi arasında anlamsal bir ilişkinin bulunduğu durumlarda, yantümce ve ana tümce eylemlerinin özneleri, [-DIK + IYYE + BUL] yapılanmasının ifade ettiği göreceli zamanı etkilemektedir:
a. \#[Eve geldiğimde] çoktan uyumuştum.
b. [Eve geldiğimde] çoktan uyumuştun.

(24a)'da gel- ve uyu- eylemlerinin her ikisi de birinci tekil kişi ile çekimlenmektedir. Her iki eylemin de öznelerinin aynı olması, gel- eyleminin sonralık ifade etmesine anlamsal açıdan izin vermemektedir. (24b)'de ise gel- ve uyu- eylemlerinin farklı özneler tarafından gerçekleştiriliyor olması, gel- eyleminin sonralık ifade edebilmesini sağlamaktadır. Bu durum, ana eylemin -mIştI ile biçimlendiği durumlarda hem yantümce hem de ana tümce eylemlerinin öznelerinin, [-DIK + IYYE + BUL] yapılanmasının ifade ettiği öncelik/sonralık göreceli zamanda etkisinin olduğunu göstermektedir. (24b)'de gördüğümüz, ana tümce ve yantümce öznelerinin farklı olduğu durumlarda [-DIK + IYYE + BUL] yapılanmasının ifade ettiği öncelik ve sonralık göreceli zamanlarını aşağıdaki tümcelerle daha açık bir şekilde görmek mümkündür:

\footnotetext{
${ }^{6} \mathrm{Bu}$ noktada, uyu- eyleminin bitimli (ing. telic) özelliğinin de ayrıca ele alınması ve okuyucuya açıklanması gerekliliğine değinen hakem önerisini dikkate alarak, uyu- eyleminin sözlüksel görünüş (ing. lexical aspect) özelliğini ayrıntılandıralım:

(1) Ali bir saatte/bir saat boyunca uyudu.

(2) Ali bir saatte/*bir saat boyunca iyileşti.

(2)'de iyileş- bitimli eyleminin bir saatte belirteç yapısıyla kullanılabilirken, bir saat boyunca yapısıyla dilbilgisidışılık sergilemektedir. (1)'de ise $u y u$ - eylemi her iki belirteç yapısıyla da kullanılabilmektedir. $\mathrm{Bu}$ durum, uyu- eyleminin iyileş- eyleminden daha farklı anlamsal görünüş özelliklerine sahip olduğunu, her durumda bitimli özelliği sergilemediğini, bitimsiz (ing. atelic) özelliğe de sahip olabildiğini göstermektedir. Bu nedenle, biz de çalışmamızın birçok örneğinde sözlüksel görünüş özelliklerinin etkisinden kaçınmak adına $u y u$ - eylemiyle benzer sözlüksel görünüş özelliklerini taşıyan ye-, piş- gibi eylemleri kullanmaya çalıştık. Sözlüksel görünüş üzerine daha kapsamlı bilgi için okuyucuyu Comrie (1976), Dahl (1985) ve Filip (2012)'ye yönlendiriyoruz.
} 
[Ali eve geldiğinde] uyumuştuk.

(Sonralık/Öncelik)

(i) Ali eve geldiğinde, biz çoktan uyumuştuk.

(ii) Ali eve geldi ve (Ali'nin dahil olmadı̆̆ı) biz uyuduk.

(iii) Ali eve geldi ve Ali ile ben/biz uyuduk.
[Ali eve geldiğinde] yemek pişirmiştik.
(Sonralık/Öncelik)

(i) Ali eve geldiğinde, biz çoktan yemek pişirmiştik.

(ii) Ali eve geldi ve (Ali'nin dahil olmadığı) biz yemek pişirdik.

(iii) Ali eve geldi ve Ali ile ben/biz yemek pişirmiştik.

Ana tümce ve yantümce eylemleri arasında anlamsal bir ilişkinin bulunduğu ve söz konusu eylemlerin öznelerinin farklı olduğu (25) tümcesinde, [-DIK + IYYE + BUL] yapılanması hem öncelik hem de sonralık ifade etmektedir. Bununla birlikte, eylemleri arasında anlamsal bir ilişkinin bulunmadığı ana tümce ve yantümcelerin öznelerinin farklı olduğu (26) tümcesinde de [-DIK + IYYE + BUL] yapılanması hem öncelik hem de sonralık belirtmektedir. (25) ve (26) tümcelerindeki [-DIK + İYE + BUL] yapılanmasının, bu tümcelerin altında sunduğumuz birinci (i) okumadaki gibi sonralık; ikinci (ii) ve üçüncü (iii) okumadaki gibi öncelik belirttiğini söyleyebiliriz.

Bu noktaya kadar, aralarında anlamsal bir ilişki bulunan ana tümce ve yantümce eylemlerinin edici özelliğindeki öznelerinin, ana eylemin -mIştI ile biçimlendiği durumlarda [-DIK + IYYE + BUL] yapılanmasının ifade ettiği öncelik/sonralık göreceli zamanlarda etkisi olduğunu gördük. Ana eylemin - $m I s ̧ t I$ ile biçimlendiği durumlarda, [-DIK + İYE + BUL] yapılanmasının ifade ettiği öncelik ve sonralık göreceli zamanlarını belirleyen bir diğer etmen ise ana tümce ya da yantümce öznesinin sahip olduğu anlamsal rollerdir. Ana eyleminin - $m I s ̧ t I$ ile biçimlendiği durumlarda, ana tümcenin öznesi [-EDİĊ] özelliğindeyse, öznesi [+EDİCi] özellikte olan [-DIK + İYE + BUL] yapılanması sonralık belirtmektedir (bkz. (27a)). Bunun yanı sıra, -mIştI ile biçimlenen ana eylemin öznesi [+EDİĊ] özelliğine sahipken; [-DIK + İYE + BUL] yapılanmasındaki özne [-EDİCi] özelliğini taşıyorsa [-DIk + İYE + BUL] yapılanması hem öncelik hem de sonralık belirtmektedir (bkz. (27b)). Her iki eylemin öznesinin [-EDíci] özelliğine olduğu durumlarda ise öncelik ve sonralık göreceli zamanlarını ifade etmektedir (bkz. $(27 \mathrm{c}))$ :
a. [Eve geldiğimde] yemek pişmişti.
(Sonralık)
b. [Yemek piştiğinde] eve gelmiştim.
(Öncelik/Sonralık)
(i) Yemek pişti ve sonra eve geldim.
(ii) Yemek piştiğinde, eve çoktan gelmiştim.
c. [Deprem olduğunda] elektrikler kesilmişti. (Öncelik/Sonralık)
(i) Deprem oldu ve sonra elektrikler kesildi. 
(ii) Deprem olduğunda, elektrikler çoktan kesilmişti.

(27a)'da piş- ana eyleminin öznesinin [-EDíci்] özellikte olmasından dolayı, [+EDíci்] özelliğindeki özneye sahip olan [-DIK + IYYE + BUL] yapılanması sonralık belirtmektedir. (27b)'de gel- ana eyleminin öznesinin [+EDíci]] özelliğini taşımasıyla, [EDİì] özelliğindeki özneye sahip olan [-DIK + İYE + BUL] yapılanması öncelik (i) ve sonralık (ii) ifade etmektedir. Hem yantümce hem de ana tümce eyleminin öznelerinin [-EDİi̇] özelliğge sahip olduğu (27c)' de [-DIK + IYYE + BUL] yapılanması hem öncelik (i) hem de sonralık (ii) göreceli zamanlarını belirtmektedir.

Ana eylem -mIştI ile biçimlendiğinde, [-DIK + IYYE + BUL] yapılanmasının belirli durumlarda yalnızca öncelik ya da sonralık ya da hem öncelik hem de sonralık göreceli zamanlarını ifade ettiğini gördük. Benzer durum, bitmişlik görünüşünü ifade ettiğini belirttiğimiz -DI ve -(y)DI geçmiş zaman belirticileriyle (-DIydI) çekimlenen ana eylemin bulunduğu tümcelerde yer alan [-DIK + İYE + BUL] yapılanmasında da görülmektedir. Bu doğrultuda, -mIştI ile çekimlenen ana eylem ile [-DIK + IYYE + BUL] yapılanmasının öncelik ve sonralık göreceli zamanlarını ifade ettiği durumların, ana eylemin -DIydI ile biçimlendiğinde gerçekleşip gerçekleşmediğine bakalım.

-DIydI ile çekimlenen ana eylem ile yantümce eylemi arasında anlamsal bir ilişkinin bulunduğu ve her iki eylemin de öznesinin ortak olduğu durumları şu biçimde örnekleyebiliriz:
a. [Eve geldiğimde] uyuduydum.
(Öncelik)
(i) Eve geldim ve sonra uyudum.
(ii) \#Eve geldiğimde, çoktan uyuduydum.
b. [Eve geldiğimde] yemek yediydim.
(Öncelik/Sonralık)
(i) Eve geldim ve sonra yemek yedim.
(ii) Eve geldiğimde, çoktan yemek yediydim.

(28a)' da aynı özne tarafından gerçekleştirilen eylemlerin birbirleri arasındaki anlamsal ilişki [-DIK + IYYE + BUL] yapılanmasının ifade ettiği öncelik/sonralık göreceli zamanları belirlemektedir. Söz konusu yapılanma, (28a)'nın altında sunduğumuz ikinci okumada (ii) görüldügüü üzere sonralık ifade etmemektedir. (28a-ii)'de aynı özneye sahip eylemlerden, gel- eyleminin sonralık göreceli zamanını ifade etmesi anlamsal açıdan sorunludur. Eylemler arasındaki anlamsal ilişkinin etkili olmadığı (28b)'de ise aynı özneye sahip gel- ve ye- eylemleri hem öncelik hem de sonralık durumlarını ifade edebilmektedir. (28b)' deki [-DIK + IYYE + BUL] yapılanmasının ifade ettiği öncelik ve sonralık göreceli zamanlarından öncelik okuması (28b-i)'de ve sonralık okuması ise (28b-ii)'de sunulmaktadır. 
Eyleminin -mIş- $(y) D I$ ile çekimlendiği ana tümce ile yantümcenin öznelerinin taşıdı̆̆ [ \pm EDİCi] özelliğinin, [-DIK + IYYE + BUL] yapılanmasının öncelik/sonralık belirtmesinde etkili olduğunu görmüştük (bkz. (27)). Bu durum, ana eylemin -DI-(y)DI ile çekimlendiği durumlarda da görülmektedir:
a. [Eve geldiğimde] yemek piştiydi.
(Sonralık)
b. [Yemek piştiğinde] eve geldiydim.
(Öncelik/Sonralık)
(i) Yemek pişti ve sonra eve geldim
(ii) Yemek piştiğinde, çoktan eve geldiydim.
c. [Deprem olduğunda] elektrikler kesildiydi.
(Öncelik/Sonralık)
(i) Deprem oldu ve sonra elektrikler kesildi.
(ii) Deprem olduğunda, elektrikler çoktan kesildiydi.

Ana eylem öznesi [-EDİci] özelliğine sahip olan (29a) tümcesinde, öznesi [+EDİ́i்] özelliğe sahip olan [-DIK + IYE + BUL] yapılanması sonralık göreceli zamanını ifade ederken; ana eylem öznesinin [+EDİi]] özelliğe sahip olan (29b) tümcesinde, öznesi [EDİCi] sahip olan [-DIK + İYE + BUL] yapılanması hem öncelik (i), hem de sonralık (ii) ifade etmektedir. Ana tümce ve yantümce eylemlerinin öznelerinin [-EDİci] özelliğe olduğu (29c) tümcesinde, [-DIK + IYYE + BUL] yapılanması öncelik (i) ve sonralık (ii) göreceli zamanlarının her ikisini de belirtmektedir.

[-DIK + IYYE + BUL] yapılanmasının, -mIştI ve -DIydI ile çekimlenen ana eylemin bulunduğu tümcelerde sonralık belirttiğini ancak belirli durumlarda öncelik de ifade edebildiğini gördük. Ana eylemin -mIştI ve -DIydI ile çekimlendiği durumlar haricinde, [-DIK + IYYE + BUL] yapılanmasının öncelik göreceli zamanını belirttiği durumları ayrıntılandıralım. Ana eylemin -(I)yor sürerlik görünüşü ile biçimlenmediği tümcelerde öncelik belirtmektedir:

(30) [Eve geldiğimizde] yemek yiyeceğiz/yedik.

(30)' da [-DIK + IYYE + BUL] yapılanmasındaki gel- eylemi, -(y)AcAk ve -DI biçimleriyle çekimlenen ye- ana eyleminden önce gerçekleşmektedir. Başka bir deyişle, (30) tümcesinde ilk olarak gel- eylemi gerçekleşirken, daha sonrasında ye- eylemi gerçekleşmektedir.

[-DIK + IYYE + BUL] yapılanmasının eşzamanlık, sonralık ve öncelik belirttiği durumlar aşağıdaki çizelgede sunduk: 
Çizelge 3. [-DIK + IYYE + BUL] Yapılanması ve Göreceli Zaman Anlatımları

\section{Ana Eyleme}

\begin{tabular}{|c|c|c|}
\hline \multirow[t]{2}{*}{ Eşzamanlık } & $-(I)$ yor & [Beni gördüğünde] ağlıyordum. \\
\hline & & O, [eve geldiğimde] uyuyor olacak. \\
\hline \multirow[t]{2}{*}{ Sonralık } & $-m I s ̧ t I$ & [Eve geldiğimde] camlar silinmişti. \\
\hline & $-D I y d I$ & [Eve geldiğimde] camlar silindiydi. \\
\hline \multirow[t]{3}{*}{ Öncelik } & Kip/Görünüş/Zaman & [Uyandığında] yüzünü yıkamalısın. \\
\hline & Biçimleri & [Uyandığında] yüzünü yıkadı. \\
\hline & (-(I)yor dişında) & \\
\hline
\end{tabular}

Çizelge 3 [-DIK + IYYE + BUL] yapılanmasının belirttiği göreceli zamanları ve bu göreceli zamanları belirtmesini sağlayan ana eylem biçimlerinin hangi yapılarla çekimlendiğini göstermektedir.

\section{Sonuç}

Ele aldığımız [-DIK + İYE + BUL] yapılanmasının göreceli zamanların her birini ifade edebildiği ve bu göreceli zamanların ana eylemin çekimlendiği belirli yapılarla gerçekleştirildiği sonucuna vardık. [-DIK + İYE + BUL] yapılanmasının, eşzamanlık ifade etmesi için ana eylemin -(I)yor sürerlik ekiyle çekimlenmesi gerekir. [-DIK + İYE + BUL] yapılanmasının sonralık ifade edebilmesi için ise ana eylem biçiminin -mIştI ya da -DIydI yapılarıyla çekimlenmelidir. Ancak ana eylemin bu yapılarla çekimlendiği belirli durumlarda, öncelik göreceli zamanı da ifade ettiğini gördük. Ana eylemin mIştI ve -DIydI ile çekimlendiği durumlarda, [-DIK + İYE + BUL] yapılanmasının öncelik ve sonralık göreceli zamanları hangi durumlarda ifade ettiğini temelde üç değişken altında sunabiliriz:

i. Ana tümce ve yantümce eylemleri arasında anlamsal bir ilişkinin bulunduğu durumlarda:

- Eğer eylemlerin özneleri ortak ise yalnızca öncelik ifade etmektedir:

a. Eve geldiğimde uyumuştum.

- Eğer eylemlerin özneleri farklı ise hem sonralık (bkz. (b)) hem öncelik (bkz. (c)) ifade etmektedir:

b. Eve geldiğimde uyumuştu. 
c. Eve geldiğimde (çoktan) uyumuştu.

ii. Ana tümce ve yantümce eylemleri arasında anlamsal bir ilişkinin bulunmadı̆̆̆ durumlarda:

- Eylemlerin özneleri ortak ya da farklı olsa da öncelik (bkz. (d)) ve sonralık (bkz. (e)) göreceli zamanlarının her ikisini de ifade etmektedir:

d. Eve geldiğimde/Eve geldiğinde yemek yemiştim.

e. Eve geldiğimde/Eve geldiğinde (çoktan) yemek yemiştim.

iii. Ana tümce ve yantümce öznelerinin [士EDíci]] anlamsal rollerinde olduğu durumlarda:

- Yantümce öznesi [+EDICi], ana tümce öznesi [-EDICi] özellikte ise yalnızca sonralık ifade etmektedir:

f. Eve geldiğimde yemek pişmişti.

- Yantümce ve ana tümce öznelerinin her ikisinin de [+EDíci] (bkz. (g)) ya da [EDİi̇] (bkz. (h)) anlamsal rollerinde olduğu durumlarda ise hem sonralık hem öncelik ifade etmektedir:

g. Eve geldiğimde uyumuştu.

h. Deprem olduğunda elektrikler kesilmişti.

Ana eylemin -mIştI ya da -DIydI yapılarıyla çekimlendiği tümcelerde, [-DIK + İYE + BUL] yapılanmasının öncelik/sonralık göreceli zamanlarını belirttiği durumları yukarıda sunduk. Bu durumların dışında, [-DIK + IYYE + BUL] yapılanmasının öncelik göreceli zamanını, -(I)yor sürerlik görünüşü belirticisiyle çekimlenmemiş olan ana eylemin bulunduğu tümcelerde ifade ettiğini söyleyebiliriz.

Eşzamanlık yanı sıra hem öncelik hem de sonralık ifade ettiğini gördüğümüz [-DIK + IYYE + BUL] yapılanmasının, ana eylemin -mIştI ve -DIydI yapılanmalarıyla biçimlendiği durumlarda hem öncelik hem de sonralık belirtebildiğini saptadık. $\mathrm{Bu}$ doğrultuda, Türkçede -mIştI ve -DIydI yapılanmalarının yalnızca öncelik kodlamadığını, belirli koşullarda sonralık da ifade edebildiğini belirledik. Bununla birlikte, zamansal belirteç yantümce oluşturan [-DIK + IYYE + BUL] yapılanmasının zaman belirteçleri gibi serbest bir dizilim sergilemesi beklenmektedir. Ancak odak özellikli [-DIK + IYYE + BUL] yapılanmasının yalnızca öncelik ifade ettiğini görmüştük (bkz. (21)). Bu durum, öncelik ve sonralık ifade eden [-DIK + IYYE + BUL] yapılanmasının farklı konumlarda yer alabildiğini; sonralık ifade eden [-DIK + IYYE + 
BUL] yapılanmasının odak öbeğinden ${ }^{7}$ (ing. focus phrase) daha yukarıda konumda yer alabildiğini, öncelik ifade eden [-DIK + IYYE + BUL] yapılanmasının ise odak öbeği de dahil olmak üzere farklı konumlarda bulunabildiğini söyleyebiliriz:

a.

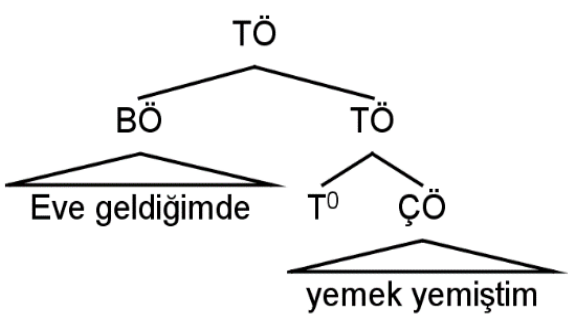

'Eve geldiğimde yemek yemiştim.' b.

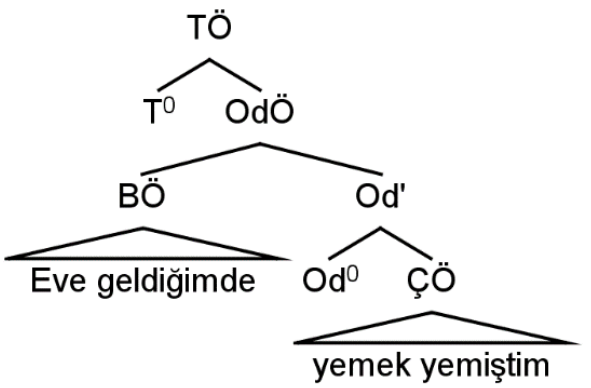

Yukarıdaki ağaç diyagramlarında yer alan belirteç öbeklerinin (BÖ) eklendikleri konumlara bakıldığında; BÖ'nün (31a)'da eklendiği tümleç öbeğini (TÖ) konumu nedeniyle hem öncelik hem de sonralık ifade ederken, (31b)'de ise eklendiği Od' (Odak) konumunda yalnızca öncelik ifade etmektedir.

Özetlemek gerekirse, -mIştI ve -DIydI yapılarının Türkçede yalnızca öncelik göreceli zamanı değil; sonralık göreceli zamanı da ifade edebildiğini gördük. Bu durum bize dilsel anlatımların dilbilgisel işlevlerinin saptanmasında anadil konuşucusu sezgilerine dayalı betimlemelerin ya da söz konusu dilsel anlatımın yazılı/sözlü dildeki görünümlerinin tanıt olarak sunumunun yeterli olmadığını, bağımsız dilbilgisel etmenlerle belirlenerek sınanabileceğini göstermektedir. Çalışmamızda bu bulguyu elde ederken bizim bağımsız bir dilbilgisel etmen olarak kullandı̆̆ımız [-DIK + İYE + BUL] yapılanmasıyla oluşturulan yantümce ile ana tümcenin öznelerinin yüklendikleri anlamsal rollerin öncelik/sonralık göreceli zaman durumlarını nasıl etkilediği sorusu hâlâ yanıtlanmamıştır. Çalışmamızın amacı doğrultusunda bu sorunun yanıtını gelecek çalışmalara bırakıyoruz.

\section{Kaynakça}

Aydemir, İ. A. (2019). Türkçede zaman ve görünüşs sistemi. Ankara: Nobel Akademik Yayıncilik.

Cinque, G. (1999). Adverbs and functional heads: A cross-linguistic perspective. New York: Oxford University Press.

\footnotetext{
${ }^{7}$ Rizzi (1997) ve odak öbeğinin konumunu, aşağıdaki (1) gösterimde olduğu gibi tümleç öbeği olarak da adlandırabileceğimiz Güç konumunun altında sunmaktadır:
}

(1) ... Güç ... (Konu) ... (Odak) . . Çekimlik ... Çekim Öbeği 
Comrie, B. (1976). Aspect. Cambridge: Cambridge University Press.

Comrie, B. (1985). Tense. Cambridge: Cambridge University Press.

Dahl, Ö. (1985). Tense and aspect systems. Oxford: Blackwell.

Filip, H. (2012). Lexical aspect. R. I. Binnick (Ed.) içinde, The Oxford handbook of tense and aspect (ss. 721-751). New York: Oxford University Press.

Göksel, A. ve Kerslake, C. (2005). Turkish: A comprehensive grammar. London: Routledge.

Haiman, J. (1980). Hua: a Papuan language of the eastern highlands of New Guinea. Amsterdam: John Benjamins.

Hengeveld, K. (1998). Adverbial clauses in the languages of Europe. J. Van der Auwera

(Ed.) içinde, Adverbial Construction in the Languages of Europe (ss. 25-145). Berlin: Mouton de Gruyter.

İşsever, S. (2000). Türkçede bilgi yapısı (Yayınlanmamış doktora tezi). Ankara Üniversitesi, Ankara.

Johanson, L. (2016). Türkçede görünüş. (N. Demir, Çev.). Ankara: Grafiker Yayınları. (Orijinal eserin yayın tarihi, 1971).

Kornfilt, J. (1997). Turkish. London, New York: Routledge.

Mufwene, S. S. (1990). Time reference in Kikongo-Kituba. J. V. Singler (Ed.) içinde, Pidgin and Creole Tense-Mood-Aspect (ss. 97-118). Amsterdam: John Benjamins.

Rizzi, L. (1997). The fine structure of the left periphery. Haegeman L. (Ed.) içinde, Elements of Grammar (ss. 281-337). Dordrecht: Springer.

Rizzi, L. ve Cinque, G. (2016). Functional categories and syntactic theory. Annual Review of Linguistics, (2), 139-163.

Sezer, E. (2001). Finite inflection in Turkish. E. Erguvanl1-Taylan (Ed.) içinde, The Verb in Turkish (ss. 1-45). Amsterdam: John Benjamins.

Underhill, R. (1976). Turkish grammar. Cambridge: MIT Press.

Uzun, N. E. (1998). Türkçe'de görünüş/kip/zaman üçlüsü. Dil Dergisi, (68), 5-22.

van Schaaik, G. (2001). Periphrastic tense/aspect/mood. E. Erguvanl1-Taylan (Ed.) içinde, The Verb in Turkish (ss. 61-95). Amsterdam: John Benjamins.

Yangın, M. T. (2020). Türkçede belirteçlerin yansıttı̆̆g işlevsel başlar ve kip-görünüş-zaman ilişkisi (Yayınlanmamış yüksek lisans tezi). Dokuz Eylül Üniversitesi, İzmir. 